\title{
REVIEW
}

\section{Pro/con debate: Is etomidate safe in hemodynamically unstable critically ill patients?}

\author{
Gordon Flynn' and Yahya Shehabi*
}

\begin{abstract}
Etomidate is an induction agent known for its smooth intubating conditions and cardiovascular stability. Studies, however, have shown that a single dose of etomidate can result in a prolonged adrenal insufficiency. The impact of this in patients with sepsis has been a matter for debate. This review presents a pro/con case for using etomidate in hemodynamically unstable critically ill patients and provides guidance for alternative induction techniques and when the use of etomidate might be justified despite these concerns.
\end{abstract}

\section{The scenario}

You are the attending intensivist in the ICU and have been consulted on a 72-year-old man who is on the medical ward and is in severe respiratory distress after a witnessed aspiration. $\mathrm{He}$ is febrile $\left(\mathrm{T}=38.6^{\circ} \mathrm{C}\right)$, tachycardic (heart rate $=120 /$ minute) and remains hypotensive (blood pressure $=86 / 35 \mathrm{mmHg}$ ) despite a $1,500 \mathrm{ml}$ intravenous bolus of normal saline. For this patient in shock, in addition to aggressive hemodynamic resuscitation it is obvious to you that he requires intubation and assisted ventilation. To facilitate intubation you wonder about the use of etomidate, but you have some concerns since you have heard that this drug may block adrenal steroid production. You are uncertain whether this agent is the right choice for this patient.

\section{Background}

Etomidate is an intravenous anaesthetic agent commonly used in emergency departments and ICUs for intubation of critically ill patients. First described in 1965, it was originally developed as an imidazole anti-fungal agent [1]. During animal testing, it was noticed to produce sedation and was introduced as a hypnotic into clinical

*Correspondence: y.shehabi@unsw.edu.au

2University of New South Wales Clinical School, Intensive Care Research, Prince of Wales Hospital, Randwick, NSW, 2031 Australia

Full list of author information is available at the end of the article practice in 1972. The pharmacodynamics of etomidate is well understood and studied. Unrelated to its hypnotic effect, etomidate strongly stimulates central $\alpha_{2}$ adrenergic receptors with characteristic lack of vasodilatation or myocardial depression, leading to little change in the heart rate or blood pressure after an induction dose of etomidate. Its intubating conditions, compared to other commonly used anaesthetic agents, and the cardiovascular stability associated with etomidate induction have made etomidate a high ranking choice for rapid sequence induction in the pre-hospital, emergency and intensive care environments, particularly in hypotensive and/or hemodynamically compromised patients with sepsis, trauma and cardiogenic shock [2-4].

\section{Pro: etomidate is safe in hemodynamically unstable critically ill patients}

Etomidate has many attractive characteristics and has been used for nearly 40 years in clinical practice, and significantly in the critically ill $[2,4]$. It has a very high therapeutic index of safety as a hypnotic agent, the lethal dose being up to 12 times the hypnotic dose, providing a good safety profile among all the other available induction agents [5-7]. Etomidate has very few cardiovascular effects and has been shown to not effect blood pressure or pulse rate [8-10]. It has a favourable kinetic profile, producing rapid onset loss of consciousness within one arm brain circulation of injection with a rapid offset due to both redistribution and metabolism via hepatic esterase with subsequent excretion, mainly via the kidney (85\%) and to a lesser degree in the biliary system, with a terminal half-life of 2 to 5 hours. The molecular pharmacology of etomidate is well understood, producing dose-dependent central nervous system depression through the facilitation of the $\alpha$ subtype of the gamma-aminobutyric acid (GABA) receptors [11,12].

Furthermore, induction with etomidate produces desirable reduction in cerebral blood flow, intracranial pressure and cerebral metabolic rate with less apnoea, almost no histamine release and very rare allergic reactions. Etomidate's safety profile has been demonstrated in animal models of haemorrhage and sepsis and in human studies [13-15]. 
Table 1. Summary of recent randomized controlled trials of etomidate

\begin{tabular}{|c|c|c|c|c|}
\hline Study & $\mathrm{N}$ & Intervention & Subjects & Main outcomes \\
\hline Absalom et al. 1999 [32] & 35 & Etomidate versus thiopentone & ASA III, two or more organ failures & $\begin{array}{l}\text { Etomidate may interfere with cortisol } \\
\text { synthesis for at least } 24 \text { hours }\end{array}$ \\
\hline Schenarts et al. 2001 [33] & 18 & Etomidate versus midazolam & $\begin{array}{l}\text { Emergency department patients } \\
\text { requiring intubation }\end{array}$ & $\begin{array}{l}\text { CST significantly different at } 4 \text { hours, same } \\
\text { response at } 12 \text { and } 24 \text { hours }\end{array}$ \\
\hline Hildreth et al. 2008 [34] & 30 & $\begin{array}{l}\text { Etomidate versus midazolam and } \\
\text { fentanyl }\end{array}$ & $\begin{array}{l}\text { Trauma patients requiring } \\
\text { intubation }\end{array}$ & $\begin{array}{l}\text { Chemical evidence of Al and may have } \\
\text { contributed to increased hospital and ICU } \\
\text { lengths of stay }\end{array}$ \\
\hline Jabre et al. 2009 [3] & 469 & Etomidate versus ketamine & $\begin{array}{l}\text { Emergency department patients } \\
\text { requiring intubation }\end{array}$ & $\begin{array}{l}\text { No difference in } 28 \text { day morbidity or } \\
\text { mortality }\end{array}$ \\
\hline Tekwani et al. 2010 [35] & 122 & Etomidate versus midazolam & $\begin{array}{l}\text { Emergency department suspected } \\
\text { sepsis requiring intubation }\end{array}$ & $\begin{array}{l}\text { No difference in mean hospital length of } \\
\text { stay, ventilator days, ICU stay or in-hospital } \\
\text { mortality }\end{array}$ \\
\hline Morel et al. 2011 [36] & 100 & Etomidate versus propofol & Elective cardiac surgery & $\begin{array}{l}\text { Etomidate blunts the HPA for more than } \\
24 \text { hours, no associated increase in } \\
\text { vasopressor requirements }\end{array}$ \\
\hline
\end{tabular}

Al adrenal insufficiency; ASA, American Society of Anesthesiologists; CST, corticotrophin stimulation test; HPA, hypothalamic pituitary axis.

\section{Con: etomidate is not safe in hemodynamically unstable critically ill patients}

Etomidate is not available around the world and is generally not the first line induction agent for elective surgical cases; this reduces exposure and familiarity with the drug amongst junior and senior doctors. Its use by infusion in trauma patients has been associated with an increase in mortality $[16,17]$ and has led to recommendations not to use etomidate in trauma patients [18]. There are alternative induction agents with similar cardiovascular stability providing the same intubating conditions, such as ketamine $[2,3,19]$. Etomidate is a hydrophobic compound associated with pain on injection but this effect has been reduced by formulation in a lipid emulsion. Myoclonic movements, trismus and postoperative nausea and vomiting are said to be more frequent with etomidate [20-23]. The main concern, however, has been the inhibition of steroid synthesis produced by etomidate.

\section{Etomidate and adrenogenesis}

Etomidate is a very potent inhibitor of steroid synthesis, acting on the adrenal gland as an inhibitor of 11betahydroxylase, a mitochondrial enzyme that converts 11-deoxycortisol to cortisol and 11-deoxycorticosterone to corticosterone $[24,25]$.

The dosage of etomidate for intravenous induction is 0.2 to $0.3 \mathrm{mg} / \mathrm{kg}$, and whilst the etomidate blood concentration required for hypnosis is of the order of $200 \mathrm{ng} / \mathrm{ml}$, a blood concentration of only $10 \mathrm{ng} / \mathrm{ml}$ can significantly reduce plasma concentrations of cortisol, cortisone and aldosterone. Indeed, low dose infusion of etomidate has been used in the treatment of Cushing's disease to suppress steroid genesis [26,27]. Although this effect is reversible, the duration of adrenal suppression after a bolus dose of etomidate remains for several hours after the hypnotic effect has worn off and much longer after prolonged infusion and in the critically ill.

Ledingham and Watt $[16,17]$ were the first to report in 1983 increased mortality, secondary to infection, in trauma patients in whom etomidate, by infusion, was the main sedative (69\% versus $25 \%$ non-etomidate recipients). Subsequent to this, the manufacturers changed the drug information leaflet to indicate that etomidate should not be used for long-term sedation. Concerns continue to be published as to whether a single bolus dose of etomidate and associated adrenal suppression cause harm in critically ill patients [28-30], particularly patients with sepsis, where there is much controversy surrounding the need for an adequate steroid response.

Malerba and colleagues [31] performed a prospective observational study to determine the factors associated with adrenal insufficiency (AI) in 62 mechanically ventilated, critically ill patients. Multivariate analysis showed that only etomidate administration was related to relative adrenocortical deficiency (odds ratio 12.21; 95\% confidence interval 2.99 to 49.74 ) for at least 24 hours. A few small randomized studies (Table 1) confirmed the adrenal insufficiency associated with a single dose of etomidate. In a randomised controlled trial comparing etomidate with thiopentone that included 35 critically ill patients requiring intubation with American Society of Anesthesiologists (ASA) scores of III or more with associated two organ failures, etomidate produced AI for up to 24 hours while thiopentone did not [32]. Schenarts and colleagues [33], in a RCT including 18 patients requiring intubation in the emergency department, used etomidate as the induction agent in 8 patients $(n=8)$ and demonstrated AI (defined as diminished response to a CST of $250 \mu \mathrm{g}$ of cosyntropin at 4 hours) that resolved by 12 hours; the other 10 patients were induced with midazolam and did not show AI. Hildreth and colleagues 
[34] demonstrated in 30 trauma patients that those who received etomidate $(\mathrm{n}=18)$ had AI compared to those given midazolam and fentanyl $(\mathrm{n}=12)$. In a prospective randomised controlled study of 122 patients with suspected sepsis comparing etomidate with midazolam for rapid sequence induction of patients meeting sepsis criteria, no significant difference could be demonstrated in length of ICU or hospital stay or in mortality [35]. Morel and colleagues [36] studied the effect of etomidate on AI and duration of vasopressors in a RCT trial of 100 patients undergoing elective cardiac surgery. They showed that etomidate $(n=50)$ increased the rate of AI but had no effect on vasopressor requirement.

Development of an etomidate analogue void of steroid inhibition is the subject of preliminary research [37]. Pejo and colleagues [38], using an endotoxaemic rat model of sepsis, demonstrated that carboetomidate, a pyrrole analogue of etomidate, produces less suppression of adrenocortical function and smaller increases in proinflammatory cytokines.

The question remains, however, whether the observed AI after a single dose of etomidate results in increased organ failure and mortality. In a relatively large RCT (KETASED collaborative study group), Jabre and colleagues randomized 655 patients requiring sedation for emergency intubation in the emergency department to $0.3 \mathrm{mg} /$ $\mathrm{kg}$ etomidate or $2 \mathrm{mg} / \mathrm{kg}$ ketamine [3]. While the intubating conditions were comparable, and the maximum Sequential Organ Failure Assessment (SOFA) scores between the two groups were not different (mean of 10.3 (standard deviation 3.7) for etomidate compared with 9.6 (3.9) for ketamine), the percentage of patients with AI was significantly higher in the etomidate group (86\%) than in the ketamine group (48\%) (odds ratio 6.7, 95\% confidence interval 3.5 to 12.7). They concluded that ketamine is a safe and valuable alternative to etomidate for endotracheal intubation in critically ill patients, and should be considered in those with sepsis.

\section{Assessment of adrenal insufficiency in ICU}

There is strong evidence that etomidate suppresses adrenal steroid production, although there are significant problems associated with assessing adrenal insufficiency in critical illness [39]. Most laboratories measure total cortisol, yet $90 \%$ of cortisol is protein bound and free cortisol is the active form responsible for biological activity. Furthermore, different assay methods have been used to assess cortisol response to the adrenalcorticotrophic (synacthen) stimulation test with wide variation in measured cortisol and response to synacthen. Cohen and colleagues showed the limits of agreement for three immunoassays with high performance liquid chromatography ranged from $-62 \%$ to $770 \%$ [40]. In addition, classifying the patients into responders and non-responders to synacthen stimulation by standard criteria produced concordance in only $44 \%$ of patients in all assays. The stimulation test for adrenal function may be performed with 1 or $250 \mu \mathrm{g}$ of synacthen, but it is still questionable what degree is considered an appropriate rise. One method of demonstrating the degree of adrenal inhibition is by measuring 11beta deoxycortisol concentration as this compound is increased when 11beta-hydroxylase is inhibited. Venkatesh and colleagues demonstrated in 21 critically ill patients that a single cortisol measurement could lead to erroneous conclusions about adrenal function [41]. In addition, different trials showed no consistency in the measurement of baseline cortisol levels and thus showed different degrees of AI in the control group [3,32-34,36].

\section{Impact on organ function and outcome}

The clinical relevance of steroid inhibition with etomidate, in the context of a single induction dose, has been a matter of significant debate. Cuthbertson and colleagues [42,43], in an a priori sub-study of the CORTICUS trial, reviewed the 96 analysable patients in the trial (out of 499) who received etomidate within 72 hours prior to inclusion. The number of patients who were non-responders to corticotropin was significantly higher than the number who received etomidate (61\% versus $44.6 \%, P=0.004)$. Etomidate was associated with a higher 28 day mortality in univariate analysis $(P=0.02)$ and after correction for severity of illness $(42.7 \%$ versus $30.5 \% ; P=0.06$ and $P=0.03)$ in multivariable models. This would appear to be strong evidence against the use of etomidate but, as the authors point out, the original study was under-powered, did not stratify at baseline for the use of etomidate and is a subgroup analysis. Like most adjusted multivariable analyses, many confounders could not have been adequately adjusted for, such as the severity of illness of the patients at the time of intubation or whether sepsis severity was adequately balanced to avoid selection bias. Furthermore, the mortality difference did not become apparent until day 10, which is well past any adrenal suppression effect of etomidate; also, there was no difference in survival in the patients given steroid replacement therapy, which should counter any AI caused by etomidate. The failure of steroid replacement to prevent potential or apparent harm associated with etomidate AI adds to the uncertainty of a possible biologically plausible link between etomidate steroid inhibition and subsequent observed mortality. Several studies investigated the administration of steroids to critically ill patients after etomidate induction. There was no benefit in duration of ventilation, ICU length of stay or 28 day mortality amongst 99 patients randomized to receive $200 \mathrm{mg}$ hydrocortisone continuous infusion per day for 2 days compared with placebo after an intubation dose of etomidate [44]. 
In a recent systematic review and meta-analysis of the effect of etomidate on adrenal function in critical illness comparing etomidate versus non-etomidate anaesthesia [45], Albert and colleagues analysed 14 studies and demonstrated an increased risk ratio for AI $(n=2,854)$ of 1.64 (range 1.52 to 1.77 ) and an increased risk ratio for mortality ( $\mathrm{n}=3,516)$ of 1.19 (1.10 to 1.30$)$; when analysed for mortality within the specific subgroup with sepsis, a total of 7 studies $(n=1,767)$, they demonstrated a statistically significant increased mortality with a risk ratio for induction with etomidate of 1.22 (95\% confidence interval 1.11 to 1.35$)$.

\section{Conclusion}

There is universal agreement and strong evidence that etomidate causes adrenal suppression even at low blood levels and after a single bolus [3,32-34,42]. There is also reasonable evidence that the duration of adrenal suppression lasts significantly longer than the hypnotic effect. However, the intensity of this suppression and its clinical significance remain inconsistent and inadequately quantified. There are also significant rates of AI in the control groups not treated with etomidate [3,32-34,42]. Although multiple reports suggested a positive association with mortality, there is no conclusive causality in septic, trauma or emergency department hypotensive patients receiving a single induction dose of etomidate.

In the context of critical illness and haemodynamic compromise, the cardiovascular stability of etomidate remains the main attraction for etomidate enthusiasts. However, there is strong evidence that other agents, such as ketamine, can offer such stability with comparable intubating conditions [3].

The definitive link between etomidate and mortality can only be confirmed in the setting of adequately powered and well designed RCTs; however, there are impediments and concerns that mean that such a trial might never be done. Firstly, etomidate is not licensed in many countries. Secondly, in countries where it is licensed, many clinicians have no equipoise and many simply do not use it. Thirdly, many may view this as a lost opportunity and therefore not worth the investment in time or money to answer this question in the presence of alternative agents and methods that offer comparable safety and efficacy. Lastly, the manufacturer probably has no commercial advantage in sponsoring such a trial. Perhaps future researchers should focus on the development of analogues of etomidate with the aim of retaining the desirable safety profile in high risk haemodynamically unstable patients whilst removing the potent inhibitory effects on adrenocorticotropic steroid synthesis.

\section{Personal opinion}

Despite the fact that etomidate is not available in Australia, in the above context we would still not use etomidate to intubate the patient in the clinical scenario presented. There are many techniques that could be deployed to intubate an unstable patient and the diligent attention to the haemodynamic status of the patient balanced against the speed with which the airway must be secured and the experience of the physician would determine the most appropriate technique and drugs. The authors would use an amnestic dose of midazolam followed by an induction dose of ketamine (anaesthesia without undue hypotension) with a small dose of fentanyl $1 \mu \mathrm{g} / \mathrm{kg}$ prior to intubation (to attenuate laryngeal reflexes). We are, however, not persuaded by the evidence against etomidate and feel that it is being unfairly tarnished by a 'no smoke without fire' attitude. Etomidate would be useful for emergent induction in unstable patients where ketamine is contraindicated, such as patients with significant coronary artery disease or suspected non-traumatic intracranial pathology with compromised intracranial and cerebrovascular dynamics. Nevertheless, in any scenario, a competent proceduralist is the key to safe and smooth induction. It is hard to believe that if the single injection of a dose of etomidate could increase the absolute mortality by greater than $10 \%$ in all patients, we would not see vast differences in survival across countries that have differing rates of use. Currently, whilst we would not use etomidate, we feel there is insufficient evidence to call for a moratorium to stop using the drug. Clinicians' attitudes and commercial reality for the manufacturer are likely to determine the fate of etomidate rather than a definitive future clinical trial.

Abbreviations

$\mathrm{Al}$, adrenal insufficiency; $\mathrm{RCT}$, randomised controlled trial.

Competing interests

The authors declare that they have no competing interests.

\section{Author details}

'Department of Intensive Care Medicine, Prince of Wales Hospital, Randwick, NSW, 2031 Australia. ${ }^{2}$ University of New South Wales Clinical School, Intensive Care Research, Prince of Wales Hospital, Randwick, NSW, 2031 Australia.

Published: 19 July 2012

\section{References}

1. Godefroi EF, Janssen PA, Vandereycken CA, Vanheertum AH, Niemegeers CJ: DL-1-(1-arylalkyl)imidazole-5-carboxylate esters. A novel type of hypnotic agents. J Med Chem 1965, 8:220-223.

2. Baird CR, Hay AW, McKeown DW, Ray DC: Rapid sequence induction in the emergency department: induction drug and outcome of patients admitted to the intensive care unit. Emerg Med J 2009, 26:576-579.

3. Jabre P, Combes X, Lapostolle F, Dhaouadi M, Ricard-Hibon A, Vivien B, Bertrand L, Beltramini A, Gamand P, Albizzati S, Perdrizet D, Lebail G, CholletXemard C, Maxime V, Brun-Buisson C, Lefrant JY, Bollaert PE, Megarbane B, Ricard JD, Anguel N, Vicaut E, Adnet F; KETASED Collaborative Study Group: Etomidate versus ketamine for rapid sequence intubation in acutely ill patients: a multicentre randomised controlled trial. Lancet 2009, 374:293-300.

4. Zed PJ, bu-Laban RB, Harrison DW: Intubating conditions and hemodynamic effects of etomidate for rapid sequence intubation in the 
emergency department: an observational cohort study. Acad Emerg Med 2006, 13:378-383.

5. Husain SS, Ziebell MR, Ruesch D, Hong F, Arevalo E, Kosterlitz JA, Olsen RW, Forman SA, Cohen JB, Miller KW: 2-(3-Methyl-3H-diaziren-3-yl)ethyl 1-(1-phenylethyl)-1H-imidazole-5-carboxylate: a derivative of the stereoselective general anesthetic etomidate for photolabeling ligandgated ion channels. J Med Chem 2003, 46:1257-1265.

6. Janssen PA, Niemegeers CJ, Schellekens KH, Lenaerts FM: Etomidate, R-(+)ethyl-1-(-methyl-benzyl)imidazole-5-carboxylate (R 16659), a potent, short-acting and relatively atoxic intravenous hypnotic agent in rats. Arzneimittelforschung 1971, 21:1234-1243.

7. Janssen PA, Niemegeers CJ, Marsboom RP: Etomidate, a potent nonbarbiturate hypnotic. Intravenous etomidate in mice, rats, guinea-pigs, rabbits and dogs. Arch Int Pharmacodyn Ther 1975, 214:92-132.

8. Criado A, Maseda J, Garcia Carmona MT, Dominguez E, Avello F: Pulmonary function and tissue oxygenation studies during anesthetic induction with etomidate. Acta Anaesthesiol Belg 1983, 34:5-13.

9. Gauss A, Heinrich H, Wilder-Smith $\mathrm{OH}$ : Echocardiographic assessment of the haemodynamic effects of propofol: a comparison with etomidate and thiopentone. Anaesthesia 1991, 46:99-105.

10. Gooding JM, Weng JT, Smith RA, Berninger GT, Kirby RR: Cardiovascular and pulmonary responses following etomidate induction of anesthesia in patients with demonstrated cardiac disease. Anesth Analg 1979, 58:40-41.

11. Forman SA: Clinical and molecular pharmacology of etomidate. Anesthesiology 2011, 114:695-707.

12. Tomlin SL, Jenkins A, Lieb WR, Franks NP: Stereoselective effects of etomidate optical isomers on gamma-aminobutyric acid type A receptors and animals. Anesthesiology 1998, 88:708-717.

13. Johnson KB, Egan TD, Layman J, Kern SE, White JL, McJames SW: The influence of hemorrhagic shock on etomidate: a pharmacokinetic and pharmacodynamic analysis. Anesth Analg 2003, 96:1360-1368, table.

14. van Lambalgen AA, van den Bos GC, Bronsveld W, Thijs LG: Comparison of two types of nonbarbiturate anesthetics during endotoxemia in dogs. Circ Shock 1986, 20:51-59.

15. Zausig YA, Busse H, Lunz D, Sinner B, Zink W, Graf BM: Cardiac effects of induction agents in the septic rat heart. Crit Care 2009, 13:R144.

16. Ledingham IM, Watt I: Influence of sedation on mortality in critically ill multiple trauma patients. Lancet 1983, 1:1270.

17. Watt I, Ledingham IM: Mortality amongst multiple trauma patients admitted to an intensive therapy unit. Anaesthesia 1984, 39:973-981

18. Bernhard M, Matthes G, Kanz KG, Waydhas C, Fischbacher M, Fischer M, Böttiger BW: [Emergency anesthesia, airway management and ventilation in major trauma. Background and key messages of the interdisciplinary S3 guidelines for major trauma patients]. Anaesthesist 2011, 60:1027-1040.

19. Jacoby J, Heller M, Nicholas J, Patel N, Cesta M, Smith G, Jacob S, Reed J: Etomidate versus midazolam for out-of-hospital intubation: a prospective, randomized trial. Ann Emerg Med 2006, 47:525-530.

20. St PM, Dunkel M, Rutherford A, Hering W: Does etomidate increase postoperative nausea? A double-blind controlled comparison of etomidate in lipid emulsion with propofol for balanced anaesthesia. Eur $J$ Anaesthesiol 2000, 17:634-641.

21. Baude C, Long D, Chabrol B, Moskovtchenko JF: [Propofol versus etomidate in short-time urologic surgery]. Ann Fr Anesth Reanim 1992, 11:12-16.

22. Fruergaard K, Jenstrup M, Schierbeck J, Wiberg-Jorgensen F: Total intravenous anaesthesia with propofol or etomidate. Eur J Anaesthesiol 1991, 8:385-391

23. Ulsamer B, Doenicke A, Laschat M: [Propofol in comparison with etomidate for the induction of anesthesia]. Anaesthesist 1986, 35:535-542.

24. Diago MC, Amado JA, Otero M, Lopez-Cordovilla JJ: Anti-adrenal action of a subanaesthetic dose of etomidate. Anaesthesia 1988, 43:644-645.

25. Fragen RJ, Shanks CA, Molteni A, Avram MJ: Effects of etomidate on hormonal responses to surgical stress. Anesthesiology 1984, 61:652-656.

26. Chan LF, Vaidya M, Westphal B, Allgrove J, Martin L, Afshar F, Hindmarsh PC, Savage MO, Grossman AB, Storr HL: Use of intravenous etomidate to control acute psychosis induced by the hypercortisolaemia in severe paediatric Cushing's disease. Horm Res Paediatr 2011, 75:441-446.

27. Feelders RA, Hofland LJ, de Herder WW: Medical treatment of Cushing's syndrome: adrenal-blocking drugs and ketaconazole. Neuroendocrinology 2010, 92 Suppl 1:111-115.

28. Annane D: ICU physicians should abandon the use of etomidate! Intensive Care Med 2005, 31:325-326.

29. Dean P: Should etomidate be used for rapid-sequence intubation induction in critically ill septic patients? Probably not. Am J Emerg Med 2008, 26:728-729.

30. Payen JF, Vinclair M, Broux C, Faure P, Chabre O: [Should etomidate still be used?]. Ann Fr Anesth Reanim 2008, 27:915-919.

31. Malerba G, Romano-Girard F, Cravoisy A, Dousset B, Nace L, Lévy B, Bollaert PE: Risk factors of relative adrenocortical deficiency in intensive care patients needing mechanical ventilation. Intensive Care Med 2005, 31:388-392.

32. Absalom A, Pledger D, Kong A: Adrenocortical function in critically ill patients $24 \mathrm{~h}$ after a single dose of etomidate. Anaesthesia 1999, 54:861-867.

33. Schenarts $\mathrm{CL}$, Burton $\mathrm{JH}$, Riker RR: Adrenocortical dysfunction following etomidate induction in emergency department patients. Acad Emerg Med 2001, 8:1-7.

34. Hildreth AN, Mejia VA, Maxwell RA, Smith PW, Dart BW, Barker DE: Adrenal suppression following a single dose of etomidate for rapid sequence induction: a prospective randomized study. J Trauma 2008, 65:573-579.

35. Tekwani KL, Watts HF, Sweis RT, Rzechula KH, Kulstad EB: A comparison of the effects of etomidate and midazolam on hospital length of stay in patients with suspected sepsis: a prospective, randomized study. Ann Emerg Med 2010, 56:481-489.

36. Morel J, Venet C, Donati Y, Charier D, Liotier J, Frere-Meunier D, Guyomarc'h S, Diconne E, Bertrand JC, Souweine B, Papazian L, Zeni F: Adrenal axis function does not appear to be associated with hemodynamic improvement in septic shock patients systematically receiving glucocorticoid therapy. Intensive Care Med 2006, 32:1184-1190.

37. Ge RL, Pejo E, Haburcak M, Husain SS, Forman SA, Raines DE: Pharmacological studies of methoxycarbonyl etomidate's carboxylic acid metabolite. Anesth Analg 2011 [Epub ahead of print].

38. Pejo E, Feng Y, Chao W, Cotten JF, Le GR, Raines DE: Differential effects of etomidate and its pyrrole analogue carboetomidate on the adrenocortical and cytokine responses to endotoxemia. Crit Care Med 2011, 40:187-192.

39. Venkatesh B, Cohen J, Hickman I, Nisbet J, Thomas P, Ward G, Hall J, Prins J: Evidence of altered cortisol metabolism in critically ill patients: a prospective study. Intensive Care Med 2007, 33:1746-1753.

40. Cohen J, Ward G, Prins J, Jones M, Venkatesh B: Variability of cortisol assays can confound the diagnosis of adrenal insufficiency in the critically ill population. Intensive Care Med 2006, 32:1901-1905.

41. Venkatesh B, Mortimer RH, Couchman B, Hall J: Evaluation of random plasma cortisol and the low dose corticotropin test as indicators of adrenal secretory capacity in critically ill patients: a prospective study. Anaesth Intensive Care 2005, 33:201-209.

42. Cuthbertson BH, Sprung CL, Annane D, Chevret S, Garfield M, Goodman S, Laterre PF, Vincent JL, Freivogel K, Reinhart K, Singer M, Payen D, Weiss YG: The effects of etomidate on adrenal responsiveness and mortality in patients with septic shock. Intensive Care Med 2009, 35:1868-1876.

43. Sprung CL, Annane D, Keh D, Moreno R, Singer M, Freivogel K, Weiss YG, Benbenishty J, Kalenka A, Forst H, Laterre PF, Reinhart K, Cuthbertson BH, Payen D, Briegel J; CORTICUS Study Group: Hydrocortisone therapy for patients with septic shock. N Engl J Med 2008, 358:111-124.

44. Payen JF, Dupuis C, Trouve-Buisson T, Vinclair M, Broux C, Bouzat P, Genty C, Monneret D, Faure P, Chabre O, Bosson $\mathrm{JL}$ : Corticosteroid after etomidate in critically ill patients: A randomized controlled trial. Crit Care Med 2011, 40:29-35.

45. Albert SG, Ariyan S, Rather A: The effect of etomidate on adrenal function in critical illness: a systematic review. Intensive Care Med 2011, 37:901-910

doi:10.1186/cc11242

Cite this article as: Flynn G, Shehabi Y: Pro/con debate: Is etomidate safe in hemodynamically unstable critically ill patients? Critical Care 2012, 16:227. 